Board of Governors of the Federal Reserve System

International Finance Discussion Papers

Number 843

October 2005

\title{
Accounting Standards and Information: Inferences from Cross-Listed Financial Firms
}

John Ammer, Nathanael Clinton, and Greg Nini

NOTE: International Finance Discussion Papers are preliminary materials circulated to stimulate discussion and critical comment. References in publications to International Finance Discussion Papers (other than an acknowledgment that the writer has had access to unpublished material) should be cleared with the author or authors. Recent IFDPs are available on the web at http://www.federalreserve.gov/pubs/ifdp/. This paper can be downloaded without charge from the Social Science Research Network electronic library at http://www.ssrn.com/. 


\title{
Accounting Standards and Information: Inferences from Cross-Listed Financial Firms
}

\author{
John Ammer, Nathanael Clinton, and Greg Nini *
}

\begin{abstract}
Publicly traded financial firms within the European Union will be required to adhere to International Accounting Standards (IAS) in their financial reporting beginning in 2005, which can entail a higher degree of financial disclosure than was previously mandated under national accounting standards. A number of European financial firms had previously subjected themselves to additional disclosure by listing their stock on U.S. exchanges, which obligates them to reconcile their financial accounts to U.S. GAAP. Among national accounting systems, U.S. GAAP is considered to be both among the strictest and the most similar to International Financial Reporting Standards (IFRS). To test whether U.S. GAAP reconciliation effectively enhances disclosure, we examine several measures of transparency for the cross-listed firms, relative both to pre-listing measures and to a control sample of firms that have not cross-listed. Our measures include bid-ask spreads, earnings forecast errors, analyst coverage, dispersion in earnings expectations, and disagreement between Moody's and S\&P's bond ratings. We find evidence that cross-listing increases transparency in at least some cases. Our crosssectional results also distinguish a handful of European financial firms that had already adopted IFRS before the European Commission announced that IAS would be required in the near future, with results similar to those of the cross-listed firms. Accordingly, to the extent that commitment to increased transparency has been a motivation for cross-listing, the adoption of IAS in Europe may reduce the incentives for European firms to cross-list in the United States.
\end{abstract}

Keywords: International Accounting Standards, bid-ask spreads, earnings estimates

JEL Classification: G14, G15, G21, G22, G28

* Ammer is a Senior Economist, Clinton is a former Research Assistant, and Nini is an Economist at the Board of Governors of the Federal Reserve System. We thank Mark Carey, Mark Flannery, Joe Gagnon, Christian Leuz, and Erlend Nier for helpful comments. The views expressed here are those of the authors and do not necessarily coincide with those of the Board of Governors of the Federal Reserve System or of any other employees of the Federal Reserve System. Email addresses: John.Ammer@frb.gov, Gregory.P.Nini@frb.gov . 
"Bankers and insurers need to fight so that the ayatollahs of mark to market [accounting] don't get their way", Claude Bebear, chairman AXA SA, as reported by Bloomberg.com on August 7, 2003.

\section{Introduction}

The above quote from the chairman of the French insurer AXA is taken from the annual shareholder meeting, where the chairman was arguing against the movement towards International Accounting Standards (IAS), which involves greater use of mark-to-market accounting principles. Publicly traded firms in European Union countries that have been using national accounting standards will be required to use IFRS beginning with their 2005 financial statements. ${ }^{1}$ For its 2002 fiscal year, AXA reported a net income of $€ 949$ million according to French GAAP and a net loss of $€ 2,588$ million according to U.S. GAAP, with much of the $€ 3.5$ billion difference attributable to market value accounting in U.S. GAAP.

Table 1 displays net income for fiscal years 2000-2002 for a sample of nineteen European banks and insurers that are cross-listed on the New York Stock Exchange (NYSE). Securities and Exchange Commission (SEC) regulations require that cross-listed firms reconcile elements of their home country accounting statements to U.S. GAAP in a filing of Form 20-F within 6 months of the home country filing. Using these publicly available figures, we find that the 2002 results from AXA are not unique. Across the other eighteen European financial firms shown in the table, the absolute value of the difference in net income ranges from -314 percent to +117 percent for the insurance companies and from -226 percent to +57 percent for the banks. The median difference is -18 percent, with a majority of the firms reporting lower net income under U.S. GAAP. The tendency for lower figures under U.S. GAAP appears to arise mainly from the

${ }^{1}$ A handful of European firms that use U.S. GAAP will be permitted to delay their switch to IFRS until their 2007 accounts. 
impact of market value accounting in a year in which stock prices declined on average, rather than factors that would necessarily make the U.S. GAAP the lower measure every year. Net income under U.S. GAAP can be much different even for firms like Allianz and UBS that compile their initial accounts under IFRS. One reason is that IAS 39, the IFRS governing treatment of financial instruments, did not require changes in the market value of assets that are held outside the trading account to flow through to net income, although these changes are reflected on the balance sheet.

Table 2 shows reconciliations to U.S. GAAP for shareholder's equity, which on average increases the figures somewhat. To the extent that the firms listed here have tended to hold assets with more unrealized capital gains than unrealized capital losses, market value accounting may again be responsible for the average difference. Differences in regulatory capital under home accounting and U.S. GAAP are not always as large as suggested here. For example, for UBS, most of the difference between shareholder's equity under U.S. GAAP and IFRS is related to goodwill that arose from the merger that created UBS, which was treated as one bank acquiring the other under U.S. GAAP (for a price in excess of the book value of the notionally acquired bank's net assets) but as a pooling of interests under IFRS, so that no goodwill arose. Conversely, goodwill is not counted as regulatory capital by U.S. bank regulators.

We use this sample of cross-listed European financial firms to make inferences about the relative transparency of U.S. GAAP versus European home country GAAP. To the extent possible, we also distinguish a small group of European financial firms that have prepared financial statements under IFRS. Note that the reconciliation to U.S. GAAP is not the only means by which a New York listing can induce transparency - U.S. disclosure requirements are enforced by the Securities and Exchange Commission (SEC), with the possibility of shareholder 
class actions suits potentially increasing the cost of concealing or distorting value-relevant information. $^{2}$

Over the past few years, IFRS have evolved to become progressively similar to U.S. GAAP, and the IASB and FASB have an active convergence project that is designed to promote international consistency in accounting standards on a forward-going basis. For example, recent changes proposed to both standards that would require equity-based compensation to be treated as a current expense included some coordination between the two governing bodies. Accordingly, a comparison of outcomes for U.S. GAAP reporting versus home-country standards offers insight into the likely effects of the upcoming migration to IFRS. Sovgyra and Theodore (2004) list several implications they expect for the financial statements of European banks that would be moving from national standards to IFRS. Generally, the same differences in treatment also arise in a comparison of European national standards to U.S. GAAP:

- Under IFRS, banks will likely have to consolidate more subsidiaries and special purpose vehicles, based on the IFRS definition of de facto control, as opposed to majority voting power.

- More assets will be measured at fair value, including embedded derivatives.

- Criteria for hedge accounting are stricter.

- Fewer securitizations will be able to be moved off the balance sheet.

- Some capital instruments will be re-classified from equity to debt (although regulatory capital will not be affected).

${ }^{2}$ In a study of price movements before and after earnings announcements, Tribukait (2003) finds indirect evidence of less insider trading for Mexican firms that have cross-listed on a U.S. stock exchange. 
- The funding status of defined benefit pension plans will be clearer.

- Rules for reserving for credit losses will change.

- Rules for deferred tax assets will change.

- Mergers will be accounted for as acquisitions, but goodwill will not be amortized mechanically (this is a recent change in IFRS that follows a similar change in U.S. GAAP).

We focus on financial firms in this paper for several reasons. First, anecdotal evidence suggests that the differences in accounting treatment can be quite severe for financial firms. In particular, differences in treatments of accounting areas such as market versus book value, financial derivatives, hedging, and "off balance sheet" transactions can have significant effects on the balance sheets and income statements of highly leveraged, asset-oriented financial enterprises. Second, prior research has suggested that financial firms are relatively opaque, making accounting transparency more important. ${ }^{3}$ Finally, the significant amount of regulatory oversight that is applied to financial firms is often justified on the basis of asymmetric information that reduces the efficacy of market-based discipline. Furthermore, compared to regulation in other industries, financial regulation (particularly capital adequacy standards), not only is typically couched in terms of accounting concepts, but tends to align regulators' interests closely with those of at least some outside investors. Accordingly, interplay between regulatory oversight and accounting standards and their effects is almost inevitable, whether as

${ }^{3}$ Theory concerning the existence of banks often highlights the production of information which is not easily verifiable to outside investors. Empirically, Morgan (2002) finds that rating agencies disagree more often for U.S. financials than a comparable set of non-financials. 
complements or substitutes.

We construct several measures of "market information" and test for significant differences between European financials firms that are cross-listed and those that only trade on a home exchange. First, we construct several measures of information based on equity analysts' earnings forecasts. We measure the dispersion across analysts' estimates, under the assumption that more disagreement reflects greater uncertainty, finding less disagreement among cross-listed firms and voluntary IFRS users than in the control group (although statistical significance is questionable for this exercise). We also consider the accuracy of the forecasts by comparing actual earnings to prior analyst forecasts. We find significantly smaller median forecast errors for cross-listed firms and voluntary IFRS users, consistent with an improved informational environment.

We also examine disagreement among credit analysts, as reflected in differences in bond credit ratings from Moody's and S\&P. Morgan (2002) shows that, among U.S. industries, credit rating disagreement is most common for banks and insurance companies, further arguing that this is evidence of the opacity of financial assets. However, we do not find significant differences in the current incidence of so-called "split ratings" between cross-listed firms, IFRS users, and European national standard users.

Finally, we draw upon the market microstructure literature to form a market-based measure of asymmetric information. Among others, Glosten and Milgrom (1985) and Kyle (1985) have shown that, all else equal, market makers must quote wider spreads if a portion of their order flow comes from better-informed traders. We collect bid-ask spreads for cross-listed firms and find that the level of spreads (in the home market) often drops significantly after cross-listing, suggesting that the adverse-selection component of the spread is reduced by cross-listing in the 
United States. This result is further supported by a cross-sectional comparison of spreads with our control group, and we also find that IFRS users trade at tighter bid-ask spreads than national standard users, even when controlling for firm size.

The remainder of the paper is organized as follows. The next section reviews the prior empirical literature that addresses the role of accounting and information. Section 2 introduces the data and hypotheses, and section 3 discusses the results. Section 4 concludes.

\section{Literature Review}

\subsection{Accounting literature comparing cross-listed firms}

The relatively modest number of financial accounts that have been prepared under IAS limits empirical research in this area, and prior work has not typically distinguished between financial and non-financial firms. One recent example is a comparison by Ashbaugh and Olsson (2002) of IAS and U.S. GAAP constructed by estimating accounting-based stock valuation models for a sample of non-U.S. foreign firms that are traded in London and report under one of the two standards. They find that a residual income model fits prices best for the U.S. GAAP firms, while an earnings capitalization framework works better for the firms using IAS. This vaguely suggests that investors interpret financial statements prepared under the two systems in a different way.

Leuz (2003) examines a sample of firms listed in Germany's Neuer Markt, a trading forum that was established in the 1990s with listing requirements that made it more accessible to newer and smaller firms than established European bourses like the Frankfurt exchange. Its promoters hoped that it would help channel capital to promising high-technology firms in Europe and thus play a role similar to that of NASDAQ in the United States. Neuer Markt firms have been 
required to produce accounts under either IAS or U.S. GAAP. Leuz finds that bid-ask spreads and trading volume for Neuer Markt firms are not affected by whether they choose IAS or U.S. GAAP, suggesting that Neuer Markt investors found the two accounting systems to be equally informative. (Under conventional market microstructure theory, an opaque accounting system would impede enforced disclosure and tend to increase the informational advantage of insiders, making it riskier for other market participants to trade, and thus reducing market liquidity.) As the author acknowledges, the sample is too limited in its scope and time frame to draw more than cautious conclusions. ${ }^{4}$

In an earlier paper, Leuz and Verecchia (2000) employ similar methodology to Leuz (2003) to assess the impact of listed German firms that switched from German accounting standard to either IAS or U.S. GAAP, when this was permitted by the German securities regulator in the late 1990s. They find that firms that moved to a non-German reporting regime enjoyed narrower bidask spreads and higher trading volume, suggesting that information asymmetry between insiders and outsiders was mitigated by better disclosure.

A number of other authors assess accounting standards in terms of whether the figures they produce help explain stock prices or returns. This is an indirect way to test accounting standards, in the sense that it determines whether investors perceive the accounting information as being informative, rather than measuring its information content directly. The methodology is also limited by strong implicit assumptions about the models that investors use to value stocks. First,

${ }^{4}$ In fact, his sample was drawn from a period during which investors, at least ex post, appear not to have been sufficiently discriminating when evaluating "new economy" firms. Subsequently, several Neuer Markt firms became embroiled in scandals related to disclosure and corporate governance questions. With most of the firms performing poorly and liquidity apparently much reduced, the Neuer Markt was closed in 2003. 
in a sample of Swiss companies, Babalyan (2002) finds that U.S. GAAP earnings are more value-relevant than figures produced under Swiss national standards, but does not find a significant difference between Swiss GAAP and IAS. Second, in a similarly conceived exercise, Eccher and Healy (2000) find that Chinese investors appear to react no more strongly to IAS accounting information than to figures produced under local accounting standards. Third, in a study of U.S.-listed firms from Australia, Canada, and the United Kingdom, Barth and Clinch (1996) find evidence that home-country and U.S. GAAP information can be complementary, in the sense that variables unique to each accounting system appear to be value relevant. Fourth, Harris and Muller (1999), find that reconciliation of earnings from IAS to U.S. GAAP is valuerelevant (although IAS has already evolved substantially since their sample was collected, including IAS 39).

Ashbaugh and Pincus (2001) use the absolute value of analysts' forecast errors as a proxy measure for (lack of) accounting transparency, arguing that large errors reflect a poor informational environment. ${ }^{5}$ For a sample of firms in the early 1990s that had not yet adopted IAS, they find that analyst forecast errors are increasing in the number of differences between the corresponding national accounting standard and IAS. In addition, absolute forecast errors decline on average when companies adopt IAS. Similarly, Lang, Lins, and Miller (2003) find that the average magnitude of earnings forecast errors decreases for firms that list in the United States, suggesting that the information environment has improved for those firms, perhaps because of the required GAAP reconciliation.

${ }^{5}$ One could also argue that earnings announcements convey less information when forecast errors are small, but that logic would be more convincing if there were more direct evidence that smaller forecast errors were associated more information in the forecasts. 


\subsection{Home bias literature}

Several recent papers in the literature on home bias produce results consistent with the notion that the increased disclosure accompanying cross-listing in the United States increases the attractiveness of related securities. For example, Doidge, Karolyi, and Stulz (2004) find evidence that, all else equal, prices are higher for cross-listed stocks. In addition, Ammer, Holland, Smith, and Warnock (2004), in an analysis of comprehensive survey data, find that listing status is the single most important variable for explaining relative U.S. holdings of foreign stocks.

\subsection{Opaqueness of financial firms}

Two recent papers explore the notion that financial firms may be less transparent than nonfinancial firms, using U.S. data. Morgan (2002) finds that, among U.S. industries, credit rating disagreement was most common for banks and insurance companies. On the other hand, the Flannery, Kwan, and Nimalendran (2002) study of the market microstructure properties U.S. bank holding companies finds relatively little difference from non-financial firms, controlling for firm size.

\section{Data and Hypotheses}

Our goal is to construct a sample of European financial firms that includes firms using three different accounting standards: cross-listed firms using U.S. GAAP, IFRS users who fulfill their home country requirements by filing using IFRS, and firms using only their home country GAAP. After constructing this sample, we collect various data on analyst earnings estimates and stock trading patterns of our sample. 


\subsection{Cross-Listed Firms and Comparison Sample}

We begin with the Bloomberg European 500 index as our potential universe of firms and then restrict our attention to firms with an industry group identified as "Banks" or "Insurance". 6 Next, we use Bloomberg to identify the subset of these firms that are traded on any U.S. exchange, which includes 21 firms with ADRs that trade on the New York Stock Exchange (NYSE) : 14 banks (commercial or money center) and 7 insurance companies (multi-line, life/health, or reinsurance). Next, using the CUSIP from Bloomberg to match our sample with Datastream, we obtain the Worldscope indicator of accounting standards (field "Acctg Standards Followed"). We use this indicator to verify the data from Bloomberg and to identify firms that are currently using IFRS. Finally, we manually inspected the annual statements of the identified firms to verify the existence of U.S. GAAP accounts (or a filed 20-F) or to identify the initial year of IFRS usage. ${ }^{7}$

This exercise produced a set of 21 cross-listed firms and 11 IFRS users from 10 different European countries. European financials tended to list in the U.S. in the mid to late 1990s, although some of our sample has been listed since the early 1990s. 9 different countries have firms that are cross-listed, with Austria being the only country with an IFRS user but no crosslisted firm. The set of IFRS users tended to switch during 1998, 1999, or 2000. Besides EFG Eurobank, the set of IFRS users are from Austria, Germany, or Switzerland, reflecting the

${ }^{6}$ Our initial search included industry group "Diversified Financials", but we found only one cross-listed firm in this group. Therefore, we have excluded this group from our analysis, except for a few instances where we could identify that the firm has banking or insurance as their principal business. These firms are part of the control group.

${ }^{7}$ One firm (Depfa Bank) was omitted because it had two unique characteristics: it reports under U.S. GAAP (only) despite not being listed in the United States, and it is incorporated in Ireland, despite having its historical roots and principal stock market listing in Germany. 
reporting requirements in these particular countries.

Our control group begins with the set of European financial firms that are not identified as cross-listed or as a user of IFRS. We assume that these firms are only traded on European exchanges and only file home country GAAP accounts. We limit this sample to firms from the 10 countries identified in our cross-listed and IFRS sample and to firms with a market capitalization at least as large as the smallest cross-listed firm. ${ }^{8}$ This exercise resulted in a set of 53 firms that form our control group sample. Table 4 reports a breakdown of our sample by country, accounting standard, and industry. Most importantly, we find that the group of local accounting firms is sufficiently large and diverse to provide a benchmark for comparison to cross-listed and IFRS firms.

\subsection{IBES Earnings Forecast Data}

We use data from the historical I/B/E/S International database to construct several measures of analyst activity and earnings forecast accuracy, which others have used to make relative comparisons about the information environments of firms. We match our set of firms to the IBES data using the IBES ticker provided by Datastream. We focus on a cross-sectional comparison of cross-listed, IFRS, and local firms rather than on a time series comparison around a change in accounting. Leuz and Verracchia (2000) suggest that increased disclosure likely happens well prior to cross-listing as the actual event simply represents a commitment to future disclosure. Bradshaw and Miller (2001) document empirically that firms move gradually towards compliance with U.S. GAAP. Moreover, we use analyst estimates at an annual frequency with relatively few observations, limiting our ability to identify the relationship

\footnotetext{
${ }^{8}$ We limited the sample to firms traded on the same set of home exchanges as the set of crosslisted and IFRS firms, but this restriction had little effect on our results.
} 
between information and a change in accounting standard.

Cross-sectional comparisons provide a more informative comparison, but identification relies on the construction of a control group that is otherwise similar to the group of cross-listed and IFRS firms. Since cross-listing and IFRS reporting are choices made by sophisticated firms, we suspect that the firms differ in other immeasurable ways. We rely on the assumption that the unobservable differences are not highly correlated with our measures of information. ${ }^{9}$

From the IBES Summary and Actual data, we collect aggregate information on the distribution of analysts' one year earnings estimates for fiscal years 1998 through 2002. For the years subsequent to 1998 , we use estimates as of the eleventh month of the fiscal year, typically four prior to the release of actual earnings. ${ }^{10}$ O'Brien and Bhushan (1990) have documented that coverage peaks in the eleventh month of the fiscal year. For 1998, we use estimates as of the first month following the close of the fiscal year, typically two months prior to the release of actual earnings. We make this adjustment so that both estimates and actual earnings are reported after the introduction of the Euro at the beginning of 1999. The data includes the number of estimates, the sample mean and median of the estimates, the sample maximum and minimum estimates, as well as the actual reported value of earnings per share. We collect data from Bloomberg on the firms share price around the release date of actual earnings and normalize earnings estimates by the average share price for the twenty trading days prior to the release of earnings. Such normalization is common in the literature since it gives an economic

${ }^{9}$ Since the value of increased disclosure is not obvious, we do not conjecture about the possible direction of the bias.

${ }^{10}$ Nearly all European firms operate on a fiscal year that coincides with the calendar year. 
interpretation to the earnings measure and permits comparisons among firms. ${ }^{11}$

We measure the amount of disagreement among analyst forecasts by the range of estimates (maximum estimate less minimum estimate), normalized by the firms average stock price prior to the actual report date. We limit the sample to firm-years with at least 5 analyst estimates and winsorize the measure at the fifth and ninety-fifth percentiles (across all firm-years) to reduce the impact of outliers. We interpret larger measures of disagreement as indicating a more opaque information environment and test the null hypothesis that disagreement does not vary with crosslisting status or IFRS usage.

We use the analyst forecast error as our primary measure of the information environment related to a firm. We use the absolute value of the difference between expected earnings and actual earnings, again standardized by stock price. For expected earnings, we report results using the sample mean estimate, although results are qualitatively robust to using the sample median. We limit the sample to firm-years with at least 5 analyst estimates and winsorize the measure at the ninetieth percentile to minimize the impact of outliers. We interpret larger forecast errors as indicating less publicly available information and test the null hypothesis that forecast errors are not correlated with cross-listing status or IFRS usage.

Note that analysts are forecasting earnings reported in the accounting standard used predominately by the firm; so analysts of cross-listed firms are forecasting home country GAAP earnings, while analysts of IFRS firms are forecasting earnings reported under IAS.

Consequently, our tests must be interpreted as identifying the relationship between increased

${ }^{11}$ We chose not to standardize by actual earnings since actual earning are often close to zero or negative. All reported results are robust to normalizing by the share price as of the date of earnings release. 
accounting disclosure and the ability to predict earnings under a different accounting scheme,

We base our statistical tests on OLS regressions that include two accounting dummy variables (indicating a cross-listed firm or an IFRS user) and a set of control variables. Our control variables are selected based on prior research on the accuracy of analysts' forecasts, as reported in Lang, Lins, and Miller (2003). Most importantly, cross-listed firms tend to be larger in size than their control group counterparts, so we control for the size of the firm since prior literature has identified a positive correlation between size and forecast accuracy. We use the log of the book value of total assets, converted to U.S. dollars, from the year-end prior to the forecast year. Second, we control for the variability of news surrounding the firm by including the annualized standard deviation of stock returns, computed using daily data for the same fiscal year as the earnings estimate. Lang and Ludholm (1996) find a negative correlation between volatility and analyst coverage, while Lang, Lins, and Miller (2003) find that volatility reduces forecast accuracy. In the forecast error regressions, we include the absolute value of the annual percentage change in earnings, taken from IBES. Lang and Ludholm (1996) suggest that forecast errors are likely a result of the magnitude of information that is disclosed. Since earnings volatility was substantial during our time period, we include a specification with this variable. The results of this specification can be interpreted relative to a naïve forecasting model of constant expected earnings. In the disagreement equation, we control for the number of estimates, since the number of analysts would affect the range of estimates even if forecasts are randomly chosen. Finally, we include a dummy variable indicating that the intermediary is predominately involved in insurance, since insurance companies may have unique forecasting properties. 


\subsection{Credit Ratings}

For the bond rating comparison, we use Moody's and Standard and Poor's (S\&P) ratings as reported by Bloomberg as of April 14, 2004. For S\&P ratings, we collect the Long-Term Local Currency Issuer Credit Rating, and for Moody's we use either the Senior Unsecured Debt Rating

or the Issuer Rating ${ }^{12}$. Ratings from both agencies were available for 43 of the firms in our sample. The most common reason for exclusion is that ratings from both agencies are not available. In our sample, both banks and insurance companies have a median Moody's rating of A1, while cross-listed and IFRS users tend to be slightly higher rated, about one notch on average. For the sample as a whole, Moody's and S\&P provided different ratings for nearly 70 percent of our sample, with banks slightly more likely to have a split rating. We estimate a probit where the dependent variable is an indicator of a split rating and an ordered probit where the dependent variable is the absolute value of the number of notches of disagreement.

\subsection{Bid-Ask Spreads}

We use Bloomberg to gather data on bid and ask prices for each of our sample firms for every trading day during 2003. The prices are based on quotes on the firm's home exchange as of the end of the day. We compute each stock's daily effective spread as the difference between the ask and the bid prices divided by the average of the two prices and measure the result in basis points. We then discard observations where the spread is negative and compute the median and trimmed mean of the sample for each firm. ${ }^{13}$ We use these variables as our measure of the

${ }^{12}$ Moody's Senior Unsecured Debt Rating and Issuer Rating are similarly defined and always matched when both available in our sample.

${ }^{13}$ We winsorize the sample at the $90^{\text {th }}$ and $95^{\text {th }}$ percentiles to compute trimmed means. Results are robust to the difference. 
spread associated with each firm.

Following Flannery, Kwan, and Nimalendran (2004), we collect additional data to construct other variables likely to affect spreads. We use 2002 year-end book value of assets to control for variation in firm size. Firm size is likely to affect the amount or quality of information available about a firm, affecting the adverse selection component of the firm's spread. Firm size may also serve as a proxy for competition among market makers in the firm's stock, since larger firms tend to be followed by more analysts. We also compute the inverse of the daily average closing price, since prior research has shown a positive relationship between spreads and this variable, likely reflecting fixed costs of market making or constraints imposed by the minimum tick size. Finally, we compute continuously compounded daily returns from 2002 price data and compute the annualized standard deviation of returns for each firm in our sample. Idiosyncratic risk creates inventory risk for market makers, which may affect spreads. We use prior year data to minimize the potential endogeneity of this variable.

\section{Empirical Results}

\subsection{Analyst Forecasts}

The top part of Table 5 shows summary statistics for the IBES sample. The first three columns report sample means by accounting standard. On a univariate basis, cross-listed and IFRS user firms have lower forecast errors, and IFRS users have substantially lower disagreement among analysts. These firms also tend to have a larger analyst following, receiving on average five to seven more estimates per firm-year than firms from the control group. Crosslisted and IFRS users are also substantially larger and have more volatile stock returns, which likely affect earnings forecasts independently of accounting differences. We control for these 
differences in our OLS regressions.

The last six columns of Table 5 show the sample maximum and minimum values for our control variables so that we can assess the comparability of the control group to the treatment groups. Other than firm size, we find that local accounting firms have sufficient variation to prove comparable to both cross-listed and IFRS user firms. However, the largest cross-listed firms and IFRS users are substantially larger than their largest local accounting peers. Consequently, in addition to controlling for size in the regressions, we test the robustness of our results by limiting the sample of treatment groups to larger firms.

Table 6 reports the results of our multivariate tests of forecast errors and analyst disagreement. Consistent with an improved informational environment, the dummy variables identifying a cross-listed firm or IFRS user are always estimated with a negative sign. In the forecast error regressions, these negative coefficients are large and statistically significant, indicating that analyst forecast errors for these firms have been substantially smaller than for their local-accounting peers during this sample period. The sample-wide average error is roughly 16 percent, so the 8 to 9 percent reduction for cross-listed and IFRS users is economically significant. Results from a Wald test suggest that the effects of cross-listing and IFRS usage are not different from each other. The results for the range of estimates regression are weaker. Although the negative point estimate for the coefficient for IFRS usage is quite sizable, it is estimated imprecisely, and neither of the accounting-standard dummies is statistically different from zero at conventional confidence levels. The combined regression results suggest that the additional disclosure required under U.S. GAAP and IAS improve analysts ability to forecast future earnings.

The effect of the control variables in the two regressions is also interesting. Insurance 
companies tend to be more opaque than their banking peers, as reflected in more disagreement among analysts and larger forecast errors. This suggests that insurance liabilities are potentially more opaque than banking assets, at least after controlling for information released in accounting statements. Firm specific volatility, as measured by the standard deviation of stock returns, significantly increases both disagreement and forecast errors, as we would expect for firms with more earnings uncertainty. The absolute value of the change in yearly earnings has a significant positive effect on forecast errors, suggesting that errors are positively related to the amount of news released. Due to the potential endogeneity of this variable, results are shown excluding this control, and the results are robust. Finally, firm size has a statistically significant and positive effect on forecast errors, which is different than typically found in other studies of forecast errors (e.g. Lang, Lins, and Miller (2003)). We suspect this difference is due to our sample being composed of financial firms, which may become more opaque as they increase in size.

Corroborating evidence is given by analyst disagreement, which also increases with firm size.

\subsection{Bid-Ask Spreads}

Table 7 reports average effective bid-ask spreads for a sample of cross-listed firms before and after the cross-listing. We compute mean spreads for 180 days before and after the date of cross-listing, excluding the 30 days around cross-listing, resulting in two means each based on 165 trading days. We exclude the days around cross-listing since the date of initial 20-F filing is ambiguous and the release of information is likely not a discrete event. We choose a relatively long window to compute averages to ensure that much of the sample is under each regime. As a robustness check, we have verified that average spreads do not display a long term trend that 
would influence our results. ${ }^{14}$

The results indicate that cross-listed firms experience a significant decrease in spreads around the time of cross-listing. The median (mean) decrease in spreads is nearly 7 (14) basis points, representing a 21 (20) percentage point decrease from pre-cross-listing levels. Many of these differences are statistically significant, and we can reject that hypothesis that the sample of pvalues is drawn from a uniform distribution. Interestingly, two of the three firms using IFRS accounting (UBS and Allianz) are part of the group of firms that do not experience a decrease in spreads around cross-listing, suggesting that the difference between IFRS and U.S. GAAP is small, particularly relative to the difference between U.S. GAAP and home country accounting standards.

It is conceivable that the decreases in bid-ask spreads that are documented in Table 7 are driven by some factor other than disclosure that is associated with U.S. cross-listing. In particular, Weston (2000) notes that rents accruing to market-makers as a result of market power can potentially affect spreads. It is conceivable that one by-product of cross-listing is increased competition from NYSE market-makers. While not a formal test, we collect spreads from the U.S. exchange (NYSE) to compare with spreads on the home market. We collect the spreads as of a particular time, the morning of April 15, 2004, a day chosen at random. The quoted spreads from Bloomberg are reported in Table 8.

On average, spreads on the home exchange are very close to spreads quoted in the U.S. The median difference suggests that the home country spreads are slightly lower by 4 basis points.

${ }^{14}$ Although we do not formally control for changes in the spreads of local accounting firms, we checked that they do not display a long term trend. Since the cross-listed firms in our sample cross-listed at different times, only a long term trend would systematically confound the results. 
Additionally, the daily average trading volume, taken over the prior 6 months, is very small in the U.S. compared to the volume traded on home exchanges, with the median ratio of NYSE volume to home exchange volume under 3 percent. We view this empirical evidence, combined with the fact that these markets are only open concurrently for a small portion of each day, as suggesting that the increased competition from NYSE market makers is likely small and unlikely to explain the large changes in spreads that we observe.

Table 9 shows the results of our cross-sectional comparison of spreads during 2003. We control for the size of the firm with the log of assets from the prior year and for the inverse of the average price during 2003. We include a dummy variable for insurance companies, and we report results for specifications with and without a control for firm-specific volatility in returns.

Focusing on the dummy variables for cross-listed and IFRS firms, we find empirical evidence that these firms have lower spreads than comparable firms that use only local accounting. The estimated coefficients suggest that cross-listed firms carry spreads that are roughly 14 basis points lower than comparable firms, while the difference for IFRS firms is roughly 23 basis points. A Wald test indicates that the difference between cross-listed firms and IFRS firms is not statistically significant. The size of the estimated effect is economically important, representing a nearly 30 percent decrease from spreads on home country only stocks. Importantly, the estimated cross-sectional impact is quite close to the effect estimated from the change in spreads around cross-listing. The failure to find a cross-sectional difference between IFRS firms and cross-listed firms is consistent with the lack of a significant change for UBS and Allianz around cross-listing.

One possibility pitfall of the simple cross-sectional we use in generating the results in Table 9 arises because the decision by each firm whether to cross-list or adopt IFRS is endogenous. In 
particular, factors that affect the costs and benefits of cross-listing or adopting IFRS might also be significantly correlated with bid-ask spreads, even when the firms' decisions are held fixed. For example, because firms that cross-list in the United States or voluntarily adopt IFRS may tend to be the types that would be more transparent and liquid whether they undertook these choices or not, we may need to correct our estimates for selection bias.

To help ensure that our Table 9 results are robust to selection bias, we implement the propensity-score method of matching, also termed "p-matching," originally developed by Rosenbaum and Rubin (1983). This methodology is based on estimates of cross-listing probabilities based on a first-stage probit model. Each of the cross-listed firms is then paired with a non-cross-listed firm according to the closeness of their propensity scores. The idea is that the bid-ask spread of p-matched non cross-listed firms are likely to be similar to what the corresponding cross-listed firm's holdings would have been if not cross-listed, so the average difference between the pairs bid-ask spreads can be used to estimate the effect of cross-listing.

The first column of Table 10 reports the results of such a first-stage probit model that reflects the cross-listing decision of our sample firms as of the end of 2002. The second column reports estimates when the firm's decision is to either cross-list or adopt IFRS, which shifts 6 additional stocks into the "treated" category. Doidge, Karolyi, and Stulz (2004) argue that there is a positive association between the proportion of shares held by insiders and the cost they incur upon cross-listing, in terms of relinquishing private control benefits through increased disclosure and monitoring. This notion is supported by the statistically significant positive effect on crosslisting we find for a measure of the proportion of a firm's shares constituted by free float. Not surprisingly, larger firms are also more likely to cross-list, and so are insurance firms (relative to banks), all else equal, in our sample. Meanwhile, the negative coefficients on the home market 
development proxy support the Ammer, Holland, Smith, and Warnock (2004) conjecture that firms from less developed financial environments may have a greater need for international capital, all else equal. Also previously suggested by Ammer, Holland, Smith, and Warnock (2004), firms from countries in which Germanic tongues predominate are more likely to crosslist or adopt IFRS, consistent with a lower cost of compliance with regulations and principles that are expressed in English.

The matched differences in average bid-ask spreads are reported in Table 11. Although neither result is significant with 95 percent confidence, we find it reassuring that our point estimates here of the effect of U.S. cross-listing are very similar to what we estimate in the Table 9 regressions.

\subsection{Credit Ratings}

In a study comparing credit ratings of U.S. corporate bonds assigned by Moody's and S\&P, Morgan (2002) finds that the two agencies disagree by at least one notch 62.9 percent of the time for bank bonds, compared to 50.0 percent for issuers from other industry sectors. (For the insurance industry, the incidence of disagreement is also higher than for non-financial firms, although there are much fewer insurance bonds in Morgan's sample.) He argues that the difference arises from banks having balance sheets that are less transparent to outsiders. We undertake an analogous comparison of rating disagreement for the 43 European firms in our sample that are rated by both agencies. If cross-listing increases transparency, then by similar logic, Moody's and S\&P's ratings ought to correspond more closely for the cross-listed firms. For S\&P ratings, we collect the Long-Term Local Currency Issuer Credit Rating, and for 
Moody's we use either the Senior Unsecured Debt Rating or the Issuer Rating ${ }^{15}$. Using ratings as of April 14, 2004 as reported on Bloomberg, we find "split ratings" for 11 of 14 cross-listed firms (78.6 percent) and for 22 of 29 that are not cross-listed (75.9 percent), virtually the same proportions. The proportions are somewhat higher than Morgan's figure for U.S. banks, suggesting that European banks are less transparent than U.S. banks, perhaps because the supervision and regulation of either banks or of issuers of securities is less effective in Europe than in the United States. However, there are a number of caveats, including the different sample period.

The estimation results in Table 12 formalize the lack of a cross-listing effect on rating disagreement. The first two columns report the results of probit models for "split" ratings. In the second specification, we also test for whether IFRS use affects ratings disagreement and control for whether the firm focuses on banking or insurance. All of the right-hand side variables are binary dummies, so we can report them in terms of the percentage impact of a unit change (starting from a case in which all dummies are zero) in the variable on the probability of a split rating; the intercept is the estimated probability when all the dummies are zero. Thus, for example, our point estimates in the first equation reflect the fact that 78.6 percent of our crosslisted firms had split ratings (75.9 percent plus 2.7 percent). Other than the intercept (where the P-value is for a null hypothesis of 50\%), none of the coefficients are even close to being statistically significant at conventional confidence levels.

${ }^{15}$ Moody's Senior Unsecured Debt Rating and Issuer Rating are similarly defined and they always matched when both available in our sample. The exercise relies on a widely accepted notion that there is a one-to-one mapping between Moody's and S\&P's ratings. In practice, historical default rates on rated bonds have differed somewhat for the corresponding rating levels, although for investment-grade ratings (for which near-term defaults are very rare events) the differences are too small to be statistically reliable. Except for Moody's rating of Scor SA, our sample is investment-grade, and mostly in the A to Aa/AA range. 
The last column reports an ordered probit for the absolute difference in ratings. The sample here includes 24 firms where the ratings differ by one notch and 8 firms where the ratings differ by two notches. Only Scor SA (which is cross-listed) has a difference of more than two notches (with Moody's rating it four notches lower than S\&P); for practical reasons, it is excluded from the ordered probit. The first intercept reflects the probability that the absolute difference is zero, and the second intercept reflects the probability that the difference is either zero or one. We find no evidence that cross-listing reduces credit rating differences. Our point estimate suggests that IFRS use reduces rating disagreements, but with only four IFRS user firms in the sample, the result is a long way from statistically significant.

Since rating agencies may have access to information beyond that available to investors, perhaps we should not be surprised that additional U.S. GAAP or IFRS disclosure has no effect on rating agency disagreement. It is certainly feasible that additional accounting disclosure provides incremental information to investors but not to rating agencies.

\section{Conclusions}

Overall, we find substantial evidence that the mandatory reconciliation to U.S. GAAP accompanying a U.S. equity listing has engendered a significant improvement in the transparency of European financial firms, at least in some cases. Moreover, firms currently using IFRS appear to have a similar degree of transparency to those firms already cross-listed. This suggests that Europe's move toward International Accounting Standards should have a similar effect on firms that are converting their financial reporting to IFRS.

Our results also may have implications for future cross-listing activity. Ammer, Holland, Smith, and Warnock (2004), for example, argue that the principal effect of cross-listing in the 
United States is a commitment to greater financial disclosure. If European firms will be facing comparable disclosure requirements at home, there may be little incentive to incur the added administrative costs (which include fees paid to the exchange) of maintaining an additional stock market listing in the United States. In fact, after rising rapidly in the 1990s, the number of European firms listed on the New York Stock Exchange has leveled off recently. Furthermore, according to an attorney that represents some cross-listed European firms, many would like to cancel their U.S. listing, but are deterred by ongoing U.S. regulatory requirements. ${ }^{16}$

${ }^{16}$ Herman Raspe, in panel discussion presentation at Wharton conference The Future of CrossBorderEquity Issuance and Trading (April 22, 2005). Under current SEC rules, a firm that terminates its listing on a U.S. securities exchange must still make regulatory filings until it can demonstrate that it has fewer than 300 U.S. shareholders. 


\section{References}

Ammer, John, Sara B. Holland, David C. Smith, and Francis E. Warnock (2004), "Look at me Now: The Role of Cross-Listing in Attracting U.S. Shareholders," International Finance Discussion Paper \#815, Federal Reserve Board (August).

Ashbaugh, Hollis and Per Olsson (2002), "An Exploratory Study of the Valuation Properties of Cross-Listed Firms' IAS and U.S. GAAP," Accounting Review (January).

Ashbaugh, Hollis and Morton Pincus (2001). "Domestic Accounting Standards, International Accounting Standards, and the Predictability of Earnings," Journal of Accounting Research 39(3):417-437.

Babalyan, Levon (2002), “Association Between Accounting Earnings and Stock Returns as a Measure of Value Relevance of Accounting Standards: Empirical Evidence from the Swiss Market," working paper, University of Fribourg.

Barth, Mary E. and Gregory J. Clinch (1996), "International Accounting Differences and their Relation to Share Prices: Evidence from U.K., Australian, and Canadian Firms," Contemporary Accounting Research 13(1), Spring.

Doidge, C., G.A. Karolyi, and R. Stulz, 2004. Why are foreign firms listed in the U.S. sorth more? Journal of Financial Economics 71, 205-238.

Eccher, Elizabeth A. and Paul M. Healy (2000), "The Role of International Accounting Standards in Transitional Economies: A Study of the People's Republic of China," working paper, Massachusetts Institute of Technology.

Flannery, Mark J., Simon H. Kwan, and M. Nimalendran (2002), "Market Evidence on the Opaqueness of Banking Firms’ Assets," Journal of Financial Economics, forthcoming.

Glosten, Lawrence R. and Paul R. Milgrom (1985), "Bid, Ask, and Transaction Prices in a Specialist Market with Heterogeneously Informed Traders," Journal of Financial Economics 14(1):71-100.

Harris, Mary S. and Karl A. Muller III (1999), "The market valuation of IAS versus US-GAAP accounting measures using Form 20-F reconciliations," Journal of Accounting and Economics 26:285-312.

Kyle, Albert S. (1985), “Continuous Auctions and Insider Trading,” Econometrica 53(6):13151336 (November).

Lang, Mark H., Karl V. Lins, and Darius Miller (2003), “ADRs, analysts, and accuracy: Does cross listing in the U.S. improve a firm's information environment and increase market value?" The Journal of Accounting Research 41. 
Lang, Mark H. and R. Lundholm (1993), "Cross-Sectional Determinants of Analyst Ratings of Corporate Disclosures," Journal of Accounting Research, 246-271.

Lang, Mark H. and R. Lundholm (1996), "Corporate Disclosure Policy and Analyst Behavior," The Accounting Review, 467-492.

Leuz, Christian (2003), "IAS versus US GAAP: Information-Asymmetry Based Evidence from Germany’s New Market," The Journal of Accounting Research 41.

Leuz, Chritsian and Robert Verrecchia (2000), "The economic consequences of increased disclosure" Journal of Accounting Research 38: 91-124.

Morgan, Donald P. (2002), "Rating Banks: Risk and Uncertainty in an Opaque Industry," American Economic Review 92: 874-888.

O’Brien, P. and R. Bhushan (1990), “Analyst follwing and institutional holding” Journal of Accounting Research, 55-76.

Rosenbaum, P. R. and D. B. Rubin (1983), The central role of the propensity score in observational studies for causal effects. Biometrika 70: 41-55.

Stickney, Clyde P. (2002), "Recent Changes in Financial Reporting Standards," working paper, Dartmouth College (June).

Tribukait, H. (2003), “The invisible enforcer? Price behavior of Mexican firms cross-listed on the NYSE around earnings announcements," Working paper, Harvard University. 
Table 1. Net Income of Cross-Listed Financial Firms Under Home Accounting Standard and Under U.S. GAAP

\begin{tabular}{|c|c|c|c|c|c|c|c|c|c|c|}
\hline \multirow[b]{2}{*}{$\underline{\text { Banks }}$} & \multirow[b]{2}{*}{ Country } & \multicolumn{3}{|c|}{ Fiscal Year 2002} & \multicolumn{2}{|c|}{ Fiscal Year 2001} & \multicolumn{2}{|c|}{ Fiscal Year 2000} & \multicolumn{2}{|c|}{$\frac{\text { Coefficient of }}{\text { Variation }(\%)}$} \\
\hline & & $\begin{array}{c}\text { Home } \\
\text { standard }\end{array}$ & $\frac{\text { U.S. }}{\underline{\text { GAAP }}}$ & $\begin{array}{c}\underline{\text { Percent }} \\
\text { difference }\end{array}$ & $\begin{array}{c}\text { Home } \\
\text { standard }\end{array}$ & $\frac{\text { U.S. }}{\underline{\text { GAAP }}}$ & $\begin{array}{c}\text { Home } \\
\text { standard }\end{array}$ & $\begin{array}{l}\text { U.S. } \\
\underline{\text { GAAP }}\end{array}$ & $\begin{array}{c}\text { Home } \\
\text { standard }\end{array}$ & $\underline{\text { U.S. }}$ \\
\hline National Bank of Greece SA & Greece & 213 & 127 & -41 & 484 & 205 & & & & \\
\hline Allied Irish Bank plc & Ireland & 1,019 & 929 & -9 & 730 & 630 & 636 & 571 & 20 & 21 \\
\hline Bank of Ireland plc & Ireland & 895 & 667 & -25 & 731 & 689 & 693 & 628 & 12 & 4 \\
\hline Sanpaolo IMI SpA & Italy & 889 & $-1,120$ & -226 & 1,203 & 571 & 1,292 & 1,003 & 16 & 100 \\
\hline ABN Amro Holding NV & Netherlands & 2,207 & 2,110 & -4 & 3,230 & 1,346 & 2,498 & 2,570 & 16 & 24 \\
\hline Banco Bilbao Vizcaya Argentaria SA & Spain & 1,719 & 1,846 & 7 & 1,843 & 680 & 1,974 & 1,413 & 6 & 32 \\
\hline Banco Santander Central Hispano SA & Spain & 2,786 & 2,287 & -18 & 3,327 & 2,177 & 3,059 & 2,009 & 8 & 6 \\
\hline Credit Suisse Group & Switzerland & $-3,309$ & $-4,741$ & -43 & 1,587 & -446 & 5,785 & 4,804 & 79 & 100 \\
\hline UBS AG (IFRS is home standard) & Switzerland & 3,535 & 5,546 & 57 & 4,973 & 3,234 & 7,792 & 4,437 & 28 & 21 \\
\hline Barclays plc & U.K. & 2,230 & 2,476 & 11 & 2,465 & 2,695 & 2,473 & 2,195 & 6 & 9 \\
\hline HSBC Holdings plc & U.K. & 6,239 & 4,900 & -21 & 4,992 & 4,911 & 6,457 & 6,236 & 12 & 12 \\
\hline Lloyds TSB Group plc & U.K. & 1,781 & 1,751 & -2 & 2,229 & 1,632 & 2,654 & 1,986 & 16 & 9 \\
\hline \multicolumn{11}{|l|}{$\underline{\text { Insurance Firms }}$} \\
\hline Axa SA & France & 949 & $-2,588$ & -373 & 520 & 356 & 3,904 & 3,248 & 47 & 90 \\
\hline Scor SA & France & -455 & 77 & 117 & -278 & -365 & 59 & -561 & 57 & 58 \\
\hline Allianz AG (IFRS is home standard) & Germany & $-1,229$ & $-1,260$ & -3 & 1,585 & 4,246 & 3,448 & 6,519 & 68 & 61 \\
\hline Aegon NV & Netherlands & 1,547 & $-2,230$ & -244 & 2,397 & 632 & 2,066 & 2,588 & 18 & 94 \\
\hline ING Groep NV & Netherlands & 4,500 & $-9,627$ & -314 & 4,577 & 1,770 & 11,984 & 10,925 & 36 & 94 \\
\hline Prudential plc & U.K. & 314 & -357 & -214 & 460 & -408 & 591 & 502 & 23 & 102 \\
\hline Royal \& Sun Alliance Group plc & U.K. & -940 & -726 & 23 & -889 & -280 & -86 & 474 & 51 & 84 \\
\hline Mean & & & & -70 & & & & & 29 & 51 \\
\hline Median & & & & -18 & & & & & 19 & 45 \\
\hline
\end{tabular}

Notes: All values are taken from fiscal year 2002 annual reports and are reported in original currency (millions). Two cross-listed firms, Deutsche Bank AG and Converium Holding AG, are omitted here because they use US GAAP as their home standard. The Coefficient of Variation is defined as the ratio of the standard deviation to the maximum (over three years). 
Table 2. Shareholders Equity of Cross-Listed Financial Firms Under Home Accounting Standard and Under U.S. GAAP

\begin{tabular}{|c|c|c|c|c|c|c|c|c|c|c|}
\hline \multirow[b]{2}{*}{$\underline{\text { Banks }}$} & \multirow[b]{2}{*}{$\underline{\text { Country }}$} & \multicolumn{3}{|c|}{ Fiscal Year 2002} & \multicolumn{2}{|c|}{ Fiscal Year 2001} & \multicolumn{2}{|c|}{$\underline{\text { Fiscal Year } 2000}$} & \multicolumn{2}{|c|}{$\frac{\text { Coefficient of }}{\text { Variation }(\%)}$} \\
\hline & & $\begin{array}{c}\text { Home } \\
\text { standard }\end{array}$ & $\frac{\text { U.S. }}{\text { GAAP }}$ & $\begin{array}{c}\text { Percent } \\
\text { difference }\end{array}$ & $\begin{array}{c}\text { Home } \\
\text { standard }\end{array}$ & $\frac{\text { U.S. }}{\text { GAAP }}$ & $\begin{array}{c}\text { Home } \\
\underline{\text { standard }}\end{array}$ & $\frac{\text { U.S. }}{\text { GAAP }}$ & $\begin{array}{c}\text { Home } \\
\text { standard }\end{array}$ & $\frac{\text { U.S. }}{\underline{\text { GAAP }}}$ \\
\hline National Bank of Greece SA & Greece & 2,584 & 1,367 & -47 & 2,578 & 1,358 & & 1,237 & & \\
\hline Allied Irish Bank plc & Ireland & 4,408 & 5,963 & 35 & 4,871 & 5,716 & 4,734 & 5,050 & 5 & 8 \\
\hline Bank of Ireland plc & Ireland & 4,200 & 4,280 & 2 & 3,830 & 4,141 & 3,305 & 3,727 & 11 & 7 \\
\hline Sanpaolo IMI SpA & Italy & 10,537 & 14,934 & 42 & 8,476 & 11,607 & 8,050 & 11,639 & 13 & 13 \\
\hline ABN Amro Holding NV & Netherlands & 26,314 & 19,013 & -28 & 29,451 & 20,856 & 27,247 & 20,222 & 5 & 4 \\
\hline Banco Bilbao Vizcaya Argentaria SA & Spain & 12,602 & 18,908 & 50 & 13,723 & 21,226 & & 22,579 & & \\
\hline Banco Santander Central Hispano SA & Spain & 24,817 & 23,114 & -7 & 28,047 & 29,944 & 27,273 & 30,929 & 6 & 14 \\
\hline Credit Suisse Group & Switzerland & 28,517 & 34,412 & 21 & 35,800 & 44,896 & 40,951 & 49,906 & 15 & 16 \\
\hline UBS AG (IFRS is home standard) & Switzerland & 38,991 & 55,576 & 43 & 43,530 & 59,282 & & & & \\
\hline Barclays plc & U.K. & 15,205 & 16,015 & 5 & 14,485 & 14,813 & & & & \\
\hline HSBC Holdings plc & U.K. & 52,406 & 55,831 & 7 & 46,388 & 48,444 & & & & \\
\hline Lloyds TSB Group plc & U.K. & 7,972 & 10,190 & 28 & 10,356 & 13,533 & & & & \\
\hline \multicolumn{11}{|l|}{$\underline{\text { Insurance Firms }}$} \\
\hline Axa SA & France & 23,711 & 23,875 & 1 & 24,780 & 29,340 & 24,322 & 31,561 & 2 & 13 \\
\hline Scor SA & France & 1,288 & 1,395 & 8 & 1,318 & 1,310 & 1,070 & 1,145 & 10 & 9 \\
\hline Allianz AG (IFRS is home standard) & Germany & 21,673 & 22,836 & 5 & 31,613 & 31,655 & 35,592 & 35,102 & 20 & 18 \\
\hline Aegon NV & Netherlands & 14,231 & 17,554 & 23 & 15,923 & 20,669 & 12,844 & 18,965 & 10 & 8 \\
\hline ING Groep NV & Netherlands & 18,300 & 25,100 & 37 & 21,500 & 38,800 & 25,300 & 41,600 & 14 & 21 \\
\hline Prudential plc & U.K. & 3,668 & 4,878 & 33 & 3,950 & 5,964 & 3,971 & 6,455 & 4 & 13 \\
\hline Royal \& Sun Alliance Group plc & U.K. & 2,918 & 2,600 & -11 & 4,566 & 4,377 & 5,911 & 5,767 & 25 & 28 \\
\hline Mean & & & & 13 & & & & & 11 & 13 \\
\hline Median & & & & 8 & & & & & 10 & 13 \\
\hline
\end{tabular}

Notes: All values are taken from fiscal year 2002 annual reports and are reported in original currency (millions). Two cross-listed firms, Deutsche Bank AG and Converium Holding AG, are omitted here because they use US GAAP as their home standard. The Coefficient of Variation is defined as the ratio of the standard deviation to the maximum (over three years). 
Table 3. European Banking and Insurance: Samples of U.S.-Listed Firms and IFRS Users

\begin{tabular}{|c|c|c|c|c|}
\hline$\underline{\text { Firm }}$ & $\underline{\text { Country }}$ & $\underline{\text { Industry }}$ & $\underline{\underline{\text { Date of }}} \underline{\underline{\text { Cross-Listing }}}$ & $\frac{\text { First IFRS }}{\underline{\text { Use }}}$ \\
\hline Axa SA & France & Insurance & June 25, 1996 & \\
\hline Scor SA & France & Insurance & October 10, 1996 & \\
\hline Deutsche Bank AG & Germany & Banking & October 3, 2001 & 1995 \\
\hline Allianz AG & Germany & Insurance & November 3, 2000 & 1998 \\
\hline National Bank of Greece & Greece & Banking & October 18, 1999 & \\
\hline Allied Irish Bank plc & Ireland & Banking & November 28, 1990 & \\
\hline Bank of Ireland plc & Ireland & Banking & September 17, 1996 & \\
\hline Sanpaolo IMI & Italy & Banking & November 2, 1998 & \\
\hline ABN Amro Holding NV & Netherlands & Banking & April 21, 1997 & \\
\hline Aegon NV & Netherlands & Insurance & November 5, 1991 & \\
\hline ING Groep NV & Netherlands & Insurance & June 13, 1997 & \\
\hline Banco Santander Central Hispano SA & Spain & Banking & July 30,1987 & \\
\hline Banco Bilbao Vizcaya Argentaria SA & Spain & Banking & December 14,1988 & \\
\hline UBS AG & Switzerland & Banking & May 16,2000 & 1998 \\
\hline Credit Suisse Group & Switzerland & Banking & September 25, 2001 & \\
\hline Converium Holding AG & Switzerland & Insurance & December 11, 2001 & \\
\hline Barclays plc & U.K. & Banking & September 9, 1986 & \\
\hline HSBC Holdings plc & U.K. & Banking & July 16,1999 & \\
\hline Lloyds TSB Group plc & U.K. & Banking & November 27, 2001 & \\
\hline Prudential plc & U.K. & Insurance & June 28,2000 & \\
\hline Royal \& Sun Alliance Group & U.K. & Insurance & October 24, 2000 & \\
\hline Bank Austria Creditanstalt & Austria & Banking & & 2000 \\
\hline Erste Bank Der Oester Spark & Austria & Banking & & 1999 \\
\hline Commerzbank AG & Germany & Banking & & 1998 \\
\hline Bayerische Hypo-Und Vereinsbank AG & Germany & Banking & & 1998 \\
\hline AMB Generali Holding AG & Germany & Insurance & & 1999 \\
\hline Muenchener Rueckver & Germany & Insurance & & 1999 \\
\hline EFG Eurobank Ergasias & Greece & Banking & & 2000 \\
\hline Julius Baer holding AG & Switzerland & Banking & & 1995 \\
\hline Baloise Holding & Switzerland & Insurance & & 2000 \\
\hline Swiss Life Holding & Switzerland & Insurance & & 2000 \\
\hline Zurich Financial Services & Switzerland & Insurance & & 1999 \\
\hline
\end{tabular}

Notes: Cross-listed firms are identified by Bloomberg as being listed on a U.S. exchange. IFRS firms are identified by Thomson Worldscope and confirmed by inspection of annual reports. Country and industry group are from Bloomberg. 
Table 4. Comparison of 2002 Cross-Listed, IFRS, and Control Group Samples

\begin{tabular}{|c|c|c|c|c|c|c|}
\hline \multirow[b]{3}{*}{ Country } & \multicolumn{4}{|c|}{ Accounting Standard } & \multicolumn{2}{|c|}{ Industry } \\
\hline & & Cross- & IFRS & & & \\
\hline & Local & Listed & User & Total & Banking & Insurance \\
\hline Austria & 1 & 0 & 2 & 3 & 2 & 1 \\
\hline France & 5 & 2 & 0 & 7 & 4 & 3 \\
\hline Germany & 5 & 2 & 4 & 11 & 7 & 4 \\
\hline Greece & 3 & 1 & 1 & 5 & 5 & 0 \\
\hline Ireland & 1 & 2 & 0 & 3 & 3 & 0 \\
\hline Italy & 21 & 1 & 0 & 22 & 16 & 6 \\
\hline Netherlands & 0 & 3 & 0 & 3 & 1 & 2 \\
\hline Spain & 4 & 2 & 0 & 6 & 5 & 1 \\
\hline Switzerland & 2 & 3 & 4 & 9 & 4 & 5 \\
\hline U.K. & 11 & 5 & 0 & 16 & 10 & 6 \\
\hline Total & 53 & 21 & 11 & 85 & 57 & 28 \\
\hline
\end{tabular}

Notes: Cross-listed and IFRS users are identical to those reported in Table 3. The control group of local accounting standards firms is based on the set of banking and insurance firms from the ten countries in Table 3 that are in the Bloomberg European 500 Index. A few firms in Bloomberg's "Diversified Financials" industry group were included because the description page indicated their principal business was either banking or insurance. 
Table 5. Summary Statistics for Cross-Listed, IFRS, and Control Group Samples

\begin{tabular}{|c|c|c|c|c|c|c|c|c|c|}
\hline \multirow[b]{2}{*}{ Variable } & \multicolumn{3}{|c|}{ Sample Mean } & \multicolumn{2}{|c|}{ Local } & \multicolumn{2}{|c|}{ Cross-Listed } & \multicolumn{2}{|c|}{ IFRS User } \\
\hline & Local & $\begin{array}{l}\text { Cross- } \\
\text { Listed } \\
\end{array}$ & $\begin{array}{l}\text { IFRS } \\
\text { User }\end{array}$ & $\begin{array}{c}\text { Sample } \\
\text { Minimum }\end{array}$ & $\begin{array}{c}\text { Sample } \\
\text { Maximum }\end{array}$ & $\begin{array}{c}\text { Sample } \\
\text { Minimum }\end{array}$ & $\begin{array}{c}\text { Sample } \\
\text { Maximum }\end{array}$ & $\begin{array}{c}\text { Sample } \\
\text { Minimum }\end{array}$ & $\begin{array}{c}\text { Sample } \\
\text { Maximum }\end{array}$ \\
\hline \multicolumn{10}{|c|}{ Analyst Earnings Sample (1998-2002) } \\
\hline Absolute Median Forecast Error & 18.7 & 14.0 & 4.5 & 0.0 & 123.6 & 0.1 & 46.4 & 0.0 & 123.6 \\
\hline Range of Forecasts & 44.1 & 44.7 & 8.4 & 0.0 & 359.9 & 0.6 & 62.6 & 0.1 & 359.9 \\
\hline Number of Estimates & 17.0 & 23.9 & 22.4 & 3.0 & 40.0 & 7.0 & 39.0 & 3.0 & 48.0 \\
\hline Insurance Firm & 0.36 & 0.37 & 0.37 & 0 & 1 & 0 & 1 & 0 & 1 \\
\hline Total Assets Prior Year & 104 & 321 & 267 & 4 & 734 & 8 & 1084 & 7 & 1250 \\
\hline Volatility Current Year & 40.4 & 43.5 & 44.1 & 8.5 & 138.1 & 22.2 & 86.1 & 26.2 & 78.5 \\
\hline Abs Value Earnings Growth & -1.0 & -16.0 & 32.0 & -66.0 & 2262.0 & -61.0 & 696.0 & -66.0 & 288.0 \\
\hline \multicolumn{10}{|l|}{ Spread Sample (2003) } \\
\hline Median Spread / Price & 47.0 & 25.6 & 49.4 & 5.6 & 190.3 & 7.1 & 68.9 & 17.4 & 173.9 \\
\hline Total Assets 2002 & 118 & 417 & 195 & 3 & 744 & 10 & 1178 & 9 & 705 \\
\hline Market Capitalization 2002 & 10 & 32 & 9 & 2 & 76 & 1 & 137 & 2 & 21 \\
\hline Inverse Average Price 2003 & 0.15 & 0.12 & 0.03 & 0.01 & 0.68 & 0.01 & 0.67 & 0.00 & 0.08 \\
\hline Return Volatility 2003 & 24 & 31 & 35 & 11 & 38 & 16 & 51 & 22 & 50 \\
\hline Insurance Firm & 0.25 & 0.38 & 0.45 & 0.00 & 1.00 & 0.00 & 1.00 & 0.00 & 1.00 \\
\hline
\end{tabular}

Notes: Summary statistics shown here correspond to the samples used in multivariate tests about analyst earnings forecast and bid-ask spreads. The analyst earnings sample covers fiscal years 1998 through 2002 while the spread sample is for 2003. Cross-listed firms and IFRS users are identified based on the information in Table 3, accounting for cross-listing date and the start of IFRS usage. Forecast error and forecast range are expressed as a percent of the stock price. Volatility and earning growth are expressed in annualized percent units. Bid-ask spreads are scaled by the mid price and expressed in basis points. Total assets and market capitalization are in billions of dollars. 
Table 6. Multivariate Test of Earnings Forecast Error and Dispersion

\begin{tabular}{|c|c|c|c|}
\hline & \multicolumn{2}{|r|}{ 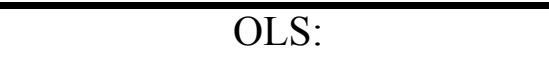 } & \multirow{2}{*}{$\begin{array}{c}\begin{array}{c}\text { OLS: } \\
\text { Range of Forecast }\end{array} \\
12.43 \\
(0.31)\end{array}$} \\
\hline$\overline{\text { Intercept }}$ & $\begin{array}{r}-0.95 \\
(0.81)\end{array}$ & $\begin{array}{r}-2.00 \\
(0.60)\end{array}$ & \\
\hline Cross-Listed & $\begin{array}{r}-8.31 \\
(0.03)\end{array}$ & $\begin{array}{r}-8.35 \\
(0.02)\end{array}$ & $\begin{array}{r}-1.76 \\
(0.82)\end{array}$ \\
\hline IFRS User & $\begin{array}{r}-9.23 \\
(0.07)\end{array}$ & $\begin{array}{r}-9.23 \\
(0.06)\end{array}$ & $\begin{array}{r}-14.44 \\
(0.18)\end{array}$ \\
\hline Insurance Firm & $\begin{array}{r}5.56 \\
(0.06)\end{array}$ & $\begin{array}{r}5.84 \\
(0.05)\end{array}$ & $\begin{array}{c}15.28 \\
(0.02)\end{array}$ \\
\hline Log Assets Prior Year & $\begin{array}{r}2.38 \\
(0.05)\end{array}$ & $\begin{array}{r}1.99 \\
(0.09)\end{array}$ & $\begin{array}{r}8.69 \\
(0.00)\end{array}$ \\
\hline Volatility Current Year & $\begin{array}{r}0.45 \\
(0.00)\end{array}$ & $\begin{array}{r}0.47 \\
(0.00)\end{array}$ & $\begin{array}{r}1.24 \\
<.0001\end{array}$ \\
\hline Abs Value Earnings Growth & $\begin{array}{r}1.89 \\
(0.02)\end{array}$ & & \\
\hline Number of Estimates & & & $\begin{array}{r}-1.23 \\
(0.00)\end{array}$ \\
\hline Country Dummy Variables & YES & YES & YES \\
\hline Adjusted R-Squared & 0.488 & 0.495 & 0.626 \\
\hline Wald Test: Cross-Listed=IFR $\subseteq$ & $\begin{array}{r}0.030 \\
(0.872)\end{array}$ & $\begin{array}{r}0.020 \\
(0.876)\end{array}$ & $\begin{array}{r}1.130 \\
(0.288)\end{array}$ \\
\hline Observations & 335 & 347 & 347 \\
\hline
\end{tabular}

Note: The dependent variable is either the absolute value of the difference between the median forecast and actual earnings or the difference between the maximum and minuimum forecasts. Both variables are standardized by the average stock price for the 20 trading days prior to the announcement of actual earnings and measured in percentage points. The sample is a set of firmyear observations treated as a pure cross-section. Volatility is the annualized standard deviation of daily stock returns during the fiscal year. Eatnings Growth is the percentage point change in yearly earnings, and Number of Estimates is the reported sample size from IBES for each firm-year. 
Table 7. Changes in Bid-Ask Spreads around Cross-Listing

\begin{tabular}{|c|c|c|c|c|c|c|}
\hline & & Bid-Ask & Bid-Ask & & Percent & \\
\hline$\underline{\text { Bank }}$ & Country & $\underline{\text { Before }}$ & After & Change & Change & $\underline{\text { P-Value }}$ \\
\hline Deutsche Bank & Germany & 27.7 & 21.0 & -6.7 & -24.2 & 0.000 \\
\hline National Bank of Greece & Greece & 46.1 & 39.2 & -6.9 & -14.9 & 0.063 \\
\hline Bank of Ireland & Ireland & 84.2 & 66.5 & -17.7 & -21.0 & 0.000 \\
\hline San Paolo & Italy & 70.9 & 59.7 & -11.2 & -15.8 & 0.017 \\
\hline ABN Amro & Netherlands & 103.0 & 45.1 & -57.8 & -56.2 & 0.000 \\
\hline Credit Suisse Group & Switzerland & 11.5 & 14.9 & 3.5 & 30.3 & 0.903 \\
\hline UBS & Switzerland & 16.2 & 18.7 & 2.5 & 15.3 & 0.977 \\
\hline HSBC & U.K. & 44.7 & 41.7 & -3.0 & -6.6 & 0.243 \\
\hline Lloyds Group & U.K. & 24.9 & 19.5 & -5.4 & -21.7 & 0.023 \\
\hline \multicolumn{7}{|l|}{$\underline{\text { Insurance Firm }}$} \\
\hline AXA & France & 23.0 & 22.0 & -1.0 & -4.4 & 0.324 \\
\hline Scor & France & 64.0 & 38.8 & -25.2 & -39.4 & 0.000 \\
\hline Allianz & Germany & 38.1 & 36.7 & -1.4 & -3.6 & 0.306 \\
\hline ING & Netherlands & 52.3 & 27.6 & -24.7 & -47.3 & 0.122 \\
\hline Prudential & U.K. & 72.5 & 36.9 & -35.6 & -49.1 & 0.000 \\
\hline Royal \& Sun Alliance & U.K. & 59.6 & 37.1 & -22.5 & -37.7 & 0.000 \\
\hline Mean & & 49.2 & 35.0 & -14.2 & -19.8 & 0.199 \\
\hline Median & & 46.1 & 36.9 & -6.9 & -21.0 & 0.023 \\
\hline
\end{tabular}

Notes: Spreads are measured as a proportion of the mid-quote price and reported in basis points. The table reports mean values for 180 trading days before and after the cross-listing date, less the 30 trading days surrounding the date itself. P-values are based on a two-tailed t distribution. 
Table 8. Trading Volume Shares and Bid-Ask Spreads: Home Market vs. New York

\begin{tabular}{|c|c|c|c|c|c|}
\hline \multirow[b]{2}{*}{ Bank } & \multirow[b]{2}{*}{ Country } & \multicolumn{3}{|c|}{ Bid-Ask Spread } & \multirow{2}{*}{$\begin{array}{r}\text { NYSE } \\
\text { Volume }\end{array}$} \\
\hline & & $\underline{\text { NYSE }}$ & $\underline{\text { Home }}$ & Difference & \\
\hline Deutsche Bank AG & Germany & 8 & 40 & -32 & $2.4 \%$ \\
\hline National Bank of Greece & Greece & 242 & 44 & 198 & $1.2 \%$ \\
\hline Allied Irish Bank PLC & Ireland & 3 & 25 & -21 & $6.2 \%$ \\
\hline Bank of Ireland PLC & Ireland & 4 & 10 & -6 & $3.2 \%$ \\
\hline Sanpaolo IMI & Italy & 30 & 10 & 20 & $1.6 \%$ \\
\hline ABN Amro Holding NV & Netherlands & 9 & 6 & 4 & $3.1 \%$ \\
\hline Banco Bilbao Vizcaya Argentaria SA & Spain & 22 & 9 & 13 & $0.5 \%$ \\
\hline Banco Santander Central Hispano SA & Spain & 27 & 11 & 16 & $0.6 \%$ \\
\hline Credit Suisse Group & Switzerland & 12 & 12 & 0 & $3.1 \%$ \\
\hline UBS AG & Switzerland & 5 & 5 & 0 & $11.4 \%$ \\
\hline Barclays PLC & U.K. & 23 & 5 & 17 & $1.5 \%$ \\
\hline HSBC Holdings PLC & U.K. & 4 & 12 & -8 & $5.2 \%$ \\
\hline Lloyds TSB Group PLC & U.K. & 10 & 6 & 4 & $0.7 \%$ \\
\hline \multicolumn{6}{|l|}{ Insurance Firm } \\
\hline Axa SA & France & 5 & 6 & -1 & $3.7 \%$ \\
\hline Scor SA & France & 117 & 70 & 47 & $12.6 \%$ \\
\hline Allianz AG & Germany & 45 & 22 & 23 & $0.8 \%$ \\
\hline Aegon NV & Netherlands & 7 & 9 & -2 & $4.4 \%$ \\
\hline ING Groep NV & Netherlands & 9 & 5 & 4 & $4.5 \%$ \\
\hline Converium Holding AG & Switzerland & 81 & 39 & 42 & $1.9 \%$ \\
\hline Prudential PLC & U.K. & 31 & 34 & -3 & $0.3 \%$ \\
\hline Royal \& Sun Alliance Group & U.K. & 88 & 29 & 59 & $0.9 \%$ \\
\hline Mean & & 37 & 19 & 18 & $3.3 \%$ \\
\hline Median & & 12 & 11 & 4 & $2.4 \%$ \\
\hline
\end{tabular}

Notes: Bid-ask spreads are measured as a proportion of the mid-quote price and reported in basis points. NYSE spreads are latest National Best Bid \& Offer as of 10:11 AM EDT on April 15, 2004. Home spreads are at the April 15, 2004 close. NYSE Volume is the ratio of composite U.S. volume to volume on the home exchange for the period from October 15, 2003 to April 14, 2004 (with U.S. volume figures adjusted for the ADR ratio to reflect the number of underlying shares). 
Table 9. Effects of Cross-Listing and IFRS Use on Bid-Ask Spreads

\begin{tabular}{|c|c|c|}
\hline \multirow[b]{2}{*}{ Intercept } & \multicolumn{2}{|c|}{$\begin{array}{c}\text { OLS: } \\
\text { Median Bid-Ask Spread / Average Price }\end{array}$} \\
\hline & $\begin{array}{r}49.6 \\
(0.000)\end{array}$ & $\begin{array}{r}50.2 \\
(0.000)\end{array}$ \\
\hline Cross-Listed & $\begin{array}{r}-13.8 \\
(0.072)\end{array}$ & $\begin{array}{r}-15.2 \\
(0.038)\end{array}$ \\
\hline IFRS User & $\begin{array}{r}-22.8 \\
(0.023)\end{array}$ & $\begin{array}{r}-31.3 \\
(0.003)\end{array}$ \\
\hline Insurance Firm & $\begin{array}{r}-7.6 \\
(0.231)\end{array}$ & $\begin{array}{r}-6.6 \\
(0.302)\end{array}$ \\
\hline Log Assets 2002 & $\begin{array}{r}-11.0 \\
(0.000)\end{array}$ & $\begin{array}{r}-10.8 \\
(0.000)\end{array}$ \\
\hline Inverse Price 2003 & $\begin{array}{r}65.3 \\
(0.001)\end{array}$ & $\begin{array}{r}66.5 \\
(0.001)\end{array}$ \\
\hline Volatility 2002 & & $\begin{array}{r}-0.2 \\
(0.596)\end{array}$ \\
\hline Country Dummy Variables & YES & YES \\
\hline Adjusted R-Squared & 0.605 & 0.665 \\
\hline Wald Test: Cross-Listed=IFRS & $\begin{array}{r}0.700 \\
(0.406)\end{array}$ & $\begin{array}{r}2.180 \\
(0.145)\end{array}$ \\
\hline Observations & 84 & 80 \\
\hline
\end{tabular}

Notes: The dependent variable here is the 2003 sample median of closing daily effective bid-ask spreads, defined as the difference between the ask and the bid, scaled by the mid price and expressed in basis points. The sample is a single cross-section. "Inverse price" is the inverse of the average daily closing price. Volatility is the annualized standard deviation of daily stock returns. P-values are shown in parentheses below estimated coefficients and test statistics. 
Table 10. Determinants of Cross-Listing and IFRS Use

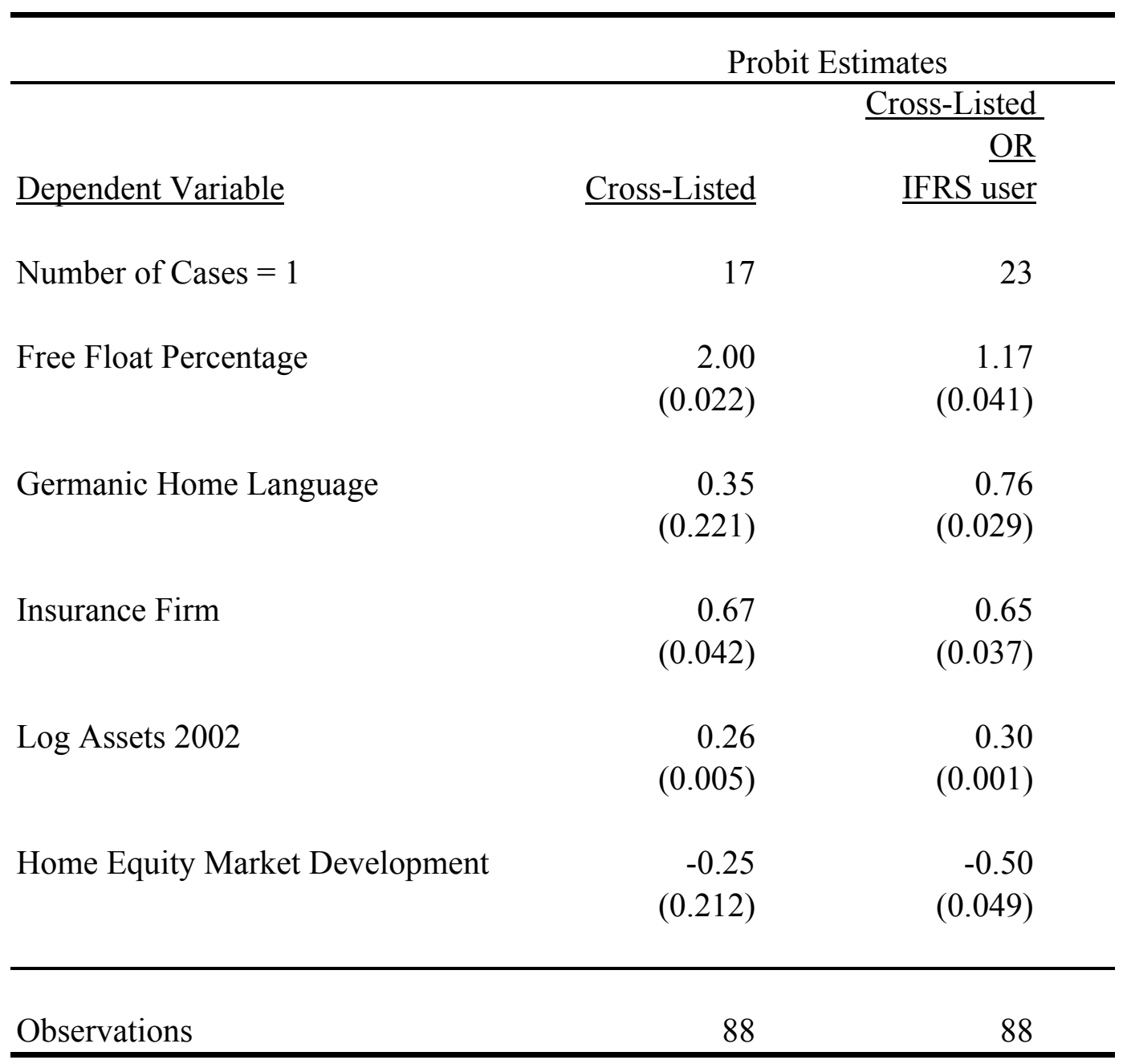

Notes: The sample is a single cross-section. "Free float percentage" is the proportion of the firm's shares that are not closely held. "Home Equity Market Development" is the ratio of 2002 national stock matket trading volume to GDP. P-values are shown in parentheses below estimated coefficients. 
Table 11. Effects on Bid-Ask Spreads by Propensity-matching

\begin{tabular}{lrr}
\hline & Mean Effective Bid-Ask Spread \\
\hline Treatment Definition & \multicolumn{1}{c}{$\begin{array}{r}\text { Cross-Listed } \\
\frac{\text { OR }}{\text { Cross-Listed }}\end{array}$} & 30.6 \\
Mean for Treated Firms & 26.8 & 46.0 \\
Mean for Matched Untreated Firms & 44.4 & -15.4 \\
Difference & -17.6 & $(0.111)$ \\
\hline Observations & $(0.078)$ & 23 \\
\hline
\end{tabular}

Notes: The measure used here is the sample median of closing daily effective bidask spreads, defined as the difference between the ask and the bid, scaled by the mid price and expressed in basis points. The results gauge the effect of "treatment" on the bid-ask spread. The samples are 2003 cross-sections that include matched pairs of all of the treated firms that couple them with non-treated firms that match them most closely in the ex ante probability of being "treated", based on the probit estimates reported in the previous table. P-values are shown in parentheses below test statistics. 
Table 12. Effects of Cross-Listing and IFRS Use on Credit Rating Agency Disagreement

\begin{tabular}{lrrr}
\hline & $\begin{array}{c}\text { Probit: } \\
\text { Rating } \\
\text { Disagreement }\end{array}$ & $\begin{array}{c}\text { Ordered Probit: } \\
\text { Absolute Rating } \\
\text { Variable }\end{array}$ \\
\hline Intercept \#1 & $75.9 \%$ & $77.2 \%$ & -0.743 \\
& $(0.006)$ & $(0.006)$ & $(0.005)$ \\
Intercept \#2 & & & 0.865 \\
& & & $(0.003)$ \\
Cross-Listed & $2.7 \%$ & & 0.189 \\
& $(0.843)$ & $(0.734)$ & $(0.641)$ \\
IFRS User & & $-2.7 \%$ & -0.427 \\
& & $(0.907)$ & $(0.646)$ \\
Insurance Firm & & & -0.167 \\
& & $-7.3 \%$ & $(0.694)$ \\
\hline
\end{tabular}

Notes: For the rating disagreement probits, the unit impact on the probability of disagreement between Moody's and S\&P is reported (all variables are binary). The estimated coefficients are reported for the ordered probit, which distinguishes among absolute rating differences of zero, one, and two ratings notches. P-values are shown in parentheses for a null hypothesis of a zero coefficient. 